\title{
A Survey on ESP Teaching in Changchun University of Science and Technology
}

\author{
Jifeng Cao \\ Changchun University of Science and Technology, Changchun, China
}

\begin{abstract}
A quantitative research on ESP teaching in Changchun University of Science and Technology was conducted. The survey shows most students are concerned about ESP teachers' English competence and subject knowledge, which are the two most important elements involved in ESP teachers' qualification. The author emphatically discusses how to improve the situation. In the long run, if more subject specialists are sent abroad for further study, they will be more qualified for ESP teaching; in the short run, joint teaching between subject specialists and language teachers could be an effective way to solve the problem. But it also involves some undecided factors.
\end{abstract}

Index Terms - ESP teaching, joint teaching, effect

\section{INTRODUCTION TO ENGLISH FOR SPECIFIC PURPOSES}

English is currently the most commonly used language in the world, especially in science and technology. In the published literature, nearly 60\% is written in English, out of the remaining 40\%, 50\% of the articles consist of English abstracts. English literature of science and technology does not necessarily come from English countries. With the development of science and technology, English has broken the national boundaries as the most effective tool for the spread and communication of science and technology in most of the research journals (Belcher \& Johns \& Paltridge, 2011). In non-English speaking countries, such as Japan and the Netherlands appear a large number of English journals for the sake of research and scientific study. There are also many kinds of English magazines in our country. At present, the rapid development of science and technology bring about the quick updating of knowledge. Without the aid of English as a great tool, we can enter the world of information technology or keep up with the development of science and technology. In such a special era, sharing knowledge is vitally necessary (Dudley-Evans \& John, 1998). From this perspective, ESP courses taught in university is a great help for students' career in the future.

Theoretically, a lot of articles refer to the origins of English for Specific Purposes. Mainly, three factors contribute to the emergence of ESP: the demands of a Brave New World, a revolution in linguistics, and focus on the learner (Hutchinson \& Waters, 1987). English for specific purposes (ESP) is totally different from specialized English. Based on the theory of Maslow's hierarchy of needs, ESP is defined to meet specific needs of the learners. For example, Hotel English as ESP is aiming to teach staff members working in a hotel so that they can give better services to people who come for business or visiting.

\section{ESPTEAching IN ChANGChun University of SCIENCE AND TECHNOLOGY}

ESP is taught in many universities of the world. Changchun University of Science and Technology is a provincial key university, which has been founded since 1958. Changchun University of Science and Technology has been aiming to develop talented students with better structure of multidisciplinary knowledge. Based on its educational philosophy and teaching features, ESP is an indispensable and important subject which can be combined with others to provide students with better structural knowledge.

In Changchun University of Science and Technology, the English course can be roughly described in the following chart.

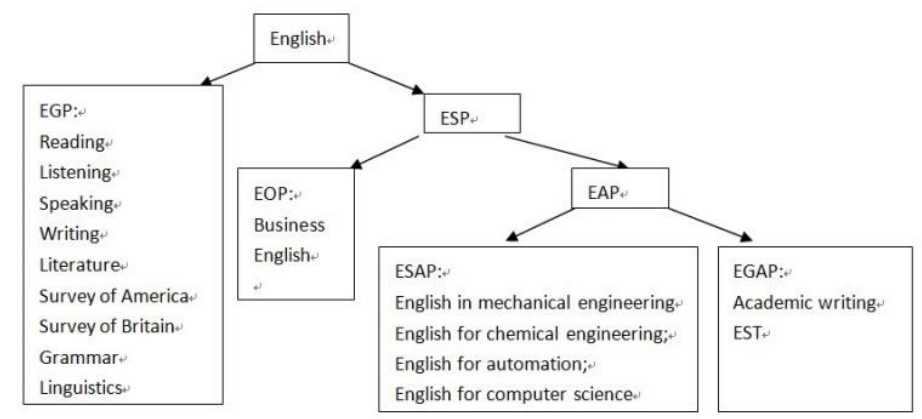

Figure 1. The main ESP courses taught in Changchun University of Science and Technology 
As we can see from the chart, there are several ESP courses provided to the students. For English majors, the main ESP course is English for science and technology. and for normal students, the ESP course are specifically designed according to their different majors, such as optical engineering English, English in mechanical engineering, English in electronics and so forth. These courses are designed in accordance with students' studying field and their majors. The purpose is simple. After finishing learning these courses, students could take use of English in their communication and learning process, especially when they step into society. Therefore, these courses not only focus on enlarging student's vocabulary of English but also aim to improve students' listening and speaking (Candlin \& Edelhoff, 1982). Hopefully, they can join English lectures, seminars and similar academic or non-academic activities. Apart from the above mentioned points, reading is also an important training activity even though most students are good at reading. The features of the ESP courses in Changchun University of Science and Technology include the following part: First, as to listening, the curriculum focuses on understanding lectures so that students are able to grasp lecturer's opinions, bring forward questions to lecturers and make arguments with the lecturer. Second, as to speaking, it centers on developing students' abilities required for taking part in seminars and presentations. For example, they need to know when they deliver a presentation they need catch the audience's attention by using necessary skills and they also need to communicate themselves clear during the presentation, so that the audience can understand him or her completely. Third, as to reading, the curriculum emphasizes understanding different styles of articles. When reading an article, the students are required to grasp the meaning of difficult sentences and also their structures (Harmer, 1983). And the articles could originate from different sources such as books, journals, magazine and even internet. Fourth, as to writing, the curriculum intends to explain how to write article involving different background knowledge. How to organize the structure of various styles of article is also an important part of the course so that students can produce high quality articles with ease. Fifth, as to the part of vocabulary, the curriculum usually sets a good list of words and expressions for students to learn and acquire. The most frequently used words and expressions are emphasized during the teaching process so that students have clear idea about the key words and their expressions. Sixth, these courses are designed to present systematic approach to developing academic skills through relevant content. Seventh, all courses intend to focus on receptive skills (reading and listening) to activate productive skills (writing and speaking) in subject area. Eighth, all the courses are designed to combine language and academic skills teaching. Ninth, further self-study or homework is a necessary part for the course designing (Robinson, 1980). The entire above mentioned are the universal requirements for the ESP courses for students in different majors.

\section{RESEARCH OBJECTIVES AND METHODOLOGY}

According to Cai Jigang and Liao Leichao, because there are not enough well-trained teachers who are both proficient in English and good at subject knowledge, ESP courses have gradually been push into a corner without being seen and valued by many universities. Now, there is a tendency that bilingual courses come to stage in most universities. Considering the demand for ESP courses, great efforts should be paid to improve the quality of ESP teaching and researching. Additionally, more funds need to be put into the field of training to get better ESP teachers in the near future (Cai \& Liao, 2010).

Whether Cai Jigang's research is universally practicable or whether it is suitable for the situation in Changchun University of Science and Technology is the author's strong concern which arouses the author's intention to do the research. These ESP courses have been performed for many years in Changchun University of Science and Technology. The basic reason for starting these courses is to provide students with better structural knowledge and better career. So many years have passed by and things for education have changed dramatically. It's reasonable for us to reconsider the purpose for providing these courses to students and the way to present them. That's the most important reason why we make this research.

Additionally, according to our investigation, both the higher vocational college and university present ESP courses in China, but the features are different. The former mostly presents English for occupational purposes such as secretarial English, tourism English, English in nursing, English used in exhibition, etc., aiming to make students to be prepared for the job through the pre-service training. Higher vocational college presents ESP courses for the service of relevant of industry, so the teaching activities developed soon and are very popular with students in higher vocational colleges.

The author adopts questionnaires and interviews as the research method in the survey. Nowadays, questionnaires and interviews are often used in the survey of people opinions for some issues. Questionnaires outweigh many other methods of research. Firstly, questionnaires don't require a big sum of money; secondly, they only need questioners to make some ticks or write a few line of words, so it has less requirements for the questioner; thirdly, because mostly the questionnaires are made of multiple choices, it's easy to convert the information from the questionnaire to another form of data which are easy to process.

However, there is also an apparent shortcoming for questionnaires. Sometimes, people who fill in the questionnaires may be too careless to understand the questions so that the real opinions may not be expressed by the way of filling out a questionnaire.

Therefore, when we design a questionnaire we need to follow some basic principle so as to avoid the shortcomings of this style of survey.

Firstly, the answer of statements in the questionnaire should not lead to a specific one. 
Secondly, spell-check is very important because it shows respect to the participant.

Thirdly, statements in the questionnaire should be definite and not ambiguous.

Fourthly, be careful about wording and make statements easy for the respondent to understand.

Fifthly, do not use negative statements or double negative statements in the questionnaire.

Questionnaire consists of 20 questions. The 20 questions consist of the following issues that the author wants to explore: first, are students satisfied with ESP courses globally? Second, what do students think of the teaching materials for the ESP courses? Third, do students think the present length of time for ESP courses is suitable or it needs to be rearranged? Fourth, what do students think of the ESP teachers' teaching strategy and teaching methods? Fifth, what do students think of ESP teachers English competence and subject knowledge.

The questionnaire uses Likert scale to scale responses in the survey research. The format of a typical five-level Likert item is taken and the respondents are asked to evaluate according to the level of agreement or disagreement is measured. Specifically, if they strongly disagree, they are supposed to choose 1; and 2 for disagree; 3 for neither agree nor disagree; 4 for agree; 5 for strongly agree.

As for the research subjects, they include both English majors and non-English major students from grade 2011 who are taking ESP courses for this semester. For English majors, the main ESP course is English for science and technology; for non-English major students, the ESP courses include engineering English, optical English and other courses. In order to study whether there are differences between the opinions of English major students' and those of non-English major students', English major students are marked as group 1 while non-English majors group 2. The questionnaires are randomly delivered to the group students and totally 200 questionnaires are given out. 188 valid questionnaires are taken back and the return rate is $94 \%$, which is enough for the analysis of the result.

\section{RESULTS AND DisCUSSION}

Table 1 shows the one-sample T test result about students' response to the statement "my ESP teacher is generally very good one compared with other subject teachers"

TABLE 1:

MY ESP TEACHER IS GENERALLY VERY GOOD ONE COMPARED WITH OTHER SUBJECT TEACHERS.

\begin{tabular}{|c|c|c|c|c|c|c|}
\hline b & $\mathrm{N}$ & Mean & Std. Deviation & Std. Error Mean & & \\
\hline $\mathrm{q} 2$ & 188 & 3.2287 & .95672 & .06978 & & \\
\hline \multicolumn{7}{|c|}{ One-Sample Test } \\
\hline ? & \multicolumn{6}{|c|}{ Test Value $=3$} \\
\hline 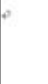 & \multirow[b]{2}{*}{ to } & \multirow[b]{2}{*}{$\mathrm{df}$} & \multirow[b]{2}{*}{ Sig. (2-tailed) } & \multirow[b]{2}{*}{ Mean Difference. } & \multicolumn{2}{|c|}{$\begin{array}{l}95 \% \text { Confidence Interval of the } \\
\text { Difference }\end{array}$} \\
\hline E & & & & & Lower & Upper \\
\hline q2 & 3.278 & 187 & .001 & .22872 & .0911 & .3664 \\
\hline
\end{tabular}

We presume that student neither agree nor disagree with this statement. But it turns out not to be. The average of the result is greater than 3 . Because $\mathrm{p}<0.05$, so we can infer that students believe outstanding professional teachers are insufficient. Since qualified teachers for ESP courses need to be proficient in spoken English but also have a good mastery of professional knowledge. This requirement is simply too high for most teachers and even those who have experience in studying aboard. This should be a severe problem to solve. Therefore, more talented teachers should be selected and sent to prestigious universities in English spoken countries for better training. After the target-based training, there could appear more qualified teachers for the ESP courses.

TABLE 2:

THE ESP TEXTBOOK USED NOW IS VERY SUITABLE FOR THE CLASSROOM TEACHING One-Sample Statistics

\begin{tabular}{|l|r|r|r|r|}
\hline & $\mathrm{N}$ & \multicolumn{1}{|c|}{ Mean } & \multicolumn{1}{|c|}{ Std. Deviation } & Std. Error Mean- \\
\hline q5. & 188 & 3.2500 & 1.05782 & .07715 \\
\hline
\end{tabular}

One-Sample Test

\begin{tabular}{|c|c|c|c|c|c|c|}
\hline \multirow{3}{*}{ 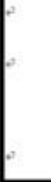 } & \multicolumn{6}{|c|}{ Test Value $=3$} \\
\hline & \multirow[b]{2}{*}{ t } & \multirow[b]{2}{*}{$\mathrm{df}$} & \multirow[b]{2}{*}{ Sig. (2-tailed) } & \multirow[b]{2}{*}{ Mean Difference. } & \multicolumn{2}{|c|}{$\begin{array}{c}95 \% \text { Confidence Interval of the } \\
\text { Difference }\end{array}$} \\
\hline & & & & & Lower. & Upper. \\
\hline q5. & 3.240 & 187. & .001 & .25000 & .0978 & .4022 \\
\hline
\end{tabular}


Table 2 shows the one-sample T test result about students' response to the statement "the ESP textbook used now is very suitable for the classroom teaching". We also presume that student neither agree nor disagree with this statement. But the average of the result is greater than 3 as well. Because $p<0.05$, so we can infer that students believe the teaching materials are improper for the class. The author believes the lack of a unified teaching material is a big problem for ESP teaching. The ESP teaching materials usually come from the following ways. First, teachers select some more professional and related articles from a certain source such as research journals (Hedge, 2002). After translating all the articles, teachers usually add some scattered notes to the articles in order to provide students with better background information. Because of the teacher's level of understanding, habits and reasons, such teaching materials are not used in wide range. Second, teachers choose published books as the teaching material. The information and knowledge present in the published book have been structural beforehand for a specific group of students, so these materials are not fully suitable for the students in CUST. And ESP teachers tend to take part of the materials out of the published book as teaching materials in ESP classes, which mean the book cannot be efficiently taken good use of (Cunningsworth, 1984). Additionally, since teachers' English level is different, they will have different when they choose the published books. And different choices of teaching material also can make a big difference for the effect of ESP classes. Sometimes ESP teachers will ask such a question as "Do ESP textbooks really exist?" This is central question we need to address. One of the problems that ESP teachers are confronted with is that they need produce a course for students in a very short period of time. Because of the time limit, it's very difficult for ESP teachers to analyze learners' need effectively or develop high-quality material for the course. So nowadays what we call ESP courses mostly don't live up to its name. In order to solve the problem, more resources need to be available for ESP teachers.

TABLE 3:

I THINK I LEARNED NECESSARY SKILLS FOR SUCCESSFUL COMMUNICATION IN A PROFESSIONAL TARGET SETTING THROUGH THE COURSE LEARNING. One-Sample Statistics

\begin{tabular}{|c|c|c|c|c|c|c|}
\hline 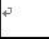 & $\mathrm{N}$ & Mean & Std. Deviation & Std. Error Mean & & \\
\hline q6. & 188 & 3.3883 & 1.03069 & .07517 & & \\
\hline \multicolumn{7}{|c|}{ One-Sample Test } \\
\hline \multirow{3}{*}{ 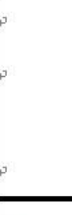 } & \multicolumn{6}{|c|}{ Test Value $=3$} \\
\hline & \multirow[b]{2}{*}{$\mathrm{t}$} & \multirow[b]{2}{*}{ df } & \multirow[b]{2}{*}{ Sig. (2-tailed) } & \multirow[b]{2}{*}{ Mean Difference } & \multicolumn{2}{|c|}{$\begin{array}{c}95 \% \text { Confidence Interval of the } \\
\text { Difference }\end{array}$} \\
\hline & & & & & Lower & Upper \\
\hline$q 6$ & 5.166 & 187 & .000 & .38830 & .2400 & .5366 \\
\hline
\end{tabular}

Table 3 shows the one-sample T test result about students' response to the statement "I think I learned necessary skills for successful communication in a professional target setting through the course learning" We presume that student neither agree nor disagree with this statement. As we can see the average number of the result is greater than 3 , too. Because $\mathrm{p}<0.05$, so we can infer that students believe students don't agree with the idea that they acquire in ESP class necessary communicational skills for specific language environment. There are two abilities necessary for successful communication in a professional target setting. The first one is that students are able to take good use of the words they learned from the course when they are in communication. They need not only know the meaning and usage of the words they learn in class, but also use them effectively in their communication. The second one is that they are able to realize what words are not suitable for daily conversation. For example, when they talk about current event over coffee time, they should realize that there is no need to use the words or expression that they learned from the ESP course. What's more, it's even unreasonable if they use the ESP words and expressions by accident. That will also be taken as a failure for their study. Or we can say that can be categorized into some kind of negative transfer. In order to make students possess these two kinds of abilities, ESP teachers need to pay more efforts when they design the course or train students in ESP class. Therefore, it will be extremely difficult for any individual to accomplish this task. Close cooperation between language teachers and subject experts will be meaningful to some extent. They can make a list, before the course design, of the possible problems they are going to face in accordance with their experience (Grant, 1987). Problem-driven approach of course designing could lead to better ideas when ESP teachers develop the course. In this way, the training part for the above mentioned two abilities could be more effectively developed. 
TABLE 4:

THE TEACHING METHOD FOR THE ESP COURSE IS SUITABLE FOR MY LEARNING.

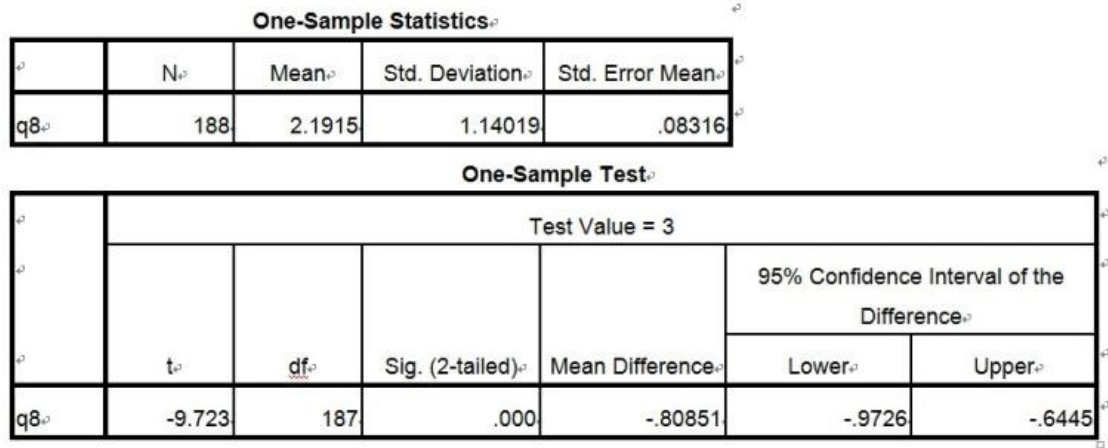

Table 4 shows the one-sample $\mathrm{T}$ test result about students' response to the statement "the teaching method for the ESP course is suitable for my learning." We presume that student neither agree nor disagree with this statement. As we can see the average number of the result is greater than 3 , too. Because $p<0.05$, so we can infer that students believe students have complaints about the teaching method used in ESP class. At present, a majority of teachers do not change the traditional teaching method when they deliver the ESP class. For example, the most frequently performed teaching activities are reading new words, translating long or difficult sentences in the whole text. The class atmosphere is usually boring. And the students tend to lose their interests forty minutes later which cause inefficient class performance. Additionally, for those students who have poorer understanding about the background knowledge and who are not competitive in English languages, they lose their interests and activeness in a quick way. According to the author's understanding, this issue is closely related to the teachers' professional level. Usually this phenomenon occurs less often in the talented teacher's class. So the key to solve the problem is to improve teachers' ability in teaching and organizing the class, and English proficiency as well.

TABLE 5:

Q12, MY ESP TEACHER'S ENGLISH IS VERY GOOD; Q13, MY ESP TEACHER HAS RICH SUBJECT KNOWLEDGE IN THIS FIELD. One-Sample Test

\begin{tabular}{|c|c|c|c|c|c|c|}
\hline \multirow{3}{*}{ 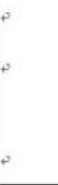 } & \multicolumn{6}{|c|}{ Test Value $=3$} \\
\hline & \multirow[b]{2}{*}{ t } & \multirow[b]{2}{*}{$\mathrm{df}$} & \multirow[b]{2}{*}{ Sig. (2-tailed) } & \multirow[b]{2}{*}{ Mean Difference } & \multicolumn{2}{|c|}{$\begin{array}{c}95 \% \text { Confidence Interval of the } \\
\text { Difference }\end{array}$} \\
\hline & & & & & Lower & Upper \\
\hline q12. & 5.090 & 96 & .000 & .32979 & .2020 & .4576 \\
\hline q13. & -10.746 & 90 & .000 & .75000 & .6123 & .8877 \\
\hline
\end{tabular}

TABLE 6:

Q12 MY ESP TEACHER'S ENGLISH IS VERY GOOD; Q13, MY ESP TEACHER HAS RICH SUBJECT KNOWLEDGE IN THIS FIELD. One-Sample Test

\begin{tabular}{|c|c|c|c|c|c|c|}
\hline \multirow{3}{*}{ 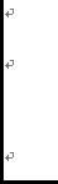 } & \multicolumn{6}{|c|}{ Test Value $=3$} \\
\hline & \multirow[b]{2}{*}{ t } & \multirow[b]{2}{*}{$\mathrm{df}$} & \multirow[b]{2}{*}{ Sig. (2-tailed) } & \multirow[b]{2}{*}{ Mean Difference } & \multicolumn{2}{|c|}{$\begin{array}{c}95 \% \text { Confidence Interval of the } \\
\text { Difference }\end{array}$} \\
\hline & & & & & Lower & Upper \\
\hline q12 & -5.929 & 90 & .000 & .43617 & .2911 & .5813 \\
\hline$q 13$ & 4.902 & 96 & .000 & .40957 & .2447 & .5744 \\
\hline
\end{tabular}

Table 5 and table 6 show the one-sample T test results about students' response to the statement "my ESP teacher's English is very good" and "My ESP teacher has rich subject knowledge in this field". It's interesting to find that Group 1 and Group 2 shows totally opposite opinion on these two statements. Group 1 stands for English majors while Group 3 stands for non-English majors. So we can infer from the result of the test that English majors think ESP teacher's English level is high enough for the course while the ESP teacher is weak in the mastery of subject knowledge. As for non-English major, their response is opposite to that of non-English majors'. It seems unreasonable to get this kind of result. but after further investigation, we find that in CUST the tradition is like this: the ESP teacher for English majors is language teach with some background knowledge to the subject while the ESP teacher for non-English majors is subject specialist whose English level is higher than other subject specialists. The response from the students will set us thinking. Maybe we should send language teachers to a certain department for learning more subject knowledge and subject specialist abroad to improve their English level. This suggestion may work eventually. But it also takes time. 
Then can we figure out a way to solve the problem quickly and effectively. The author believes joint teaching could be the answer. Virtually joint teaching had been practiced abroad early in the development of ESP teaching so as to get a better teaching result. By joint teaching we mean subject specialists cooperate with language teachers, the main purpose of the cooperation is that subject specialists could help language teachers in ESP teaching since subject specialists have better understanding of the subject taught while language teachers have better mastery of the language. And this way of teaching has been still in use today in some countries. In this form of cooperation, subject specialists can help language teaching in the following way:

First, help describe the scene in the target language and provide information on possible learning difficulties;

Second, offering a reading list, including the recommended professional magazine, charts, etc;

Third, help collect teaching materials;

Fourth, help make short video or tapes involving the professional content;

Fifth, help students to do professional knowledge lecture and organize small academic seminars.

Apart from the content of the cooperation, we also need to discuss the form of it. We usually can divide the cooperation into two types, namely, in class and out of class. The subject specialist can join the teaching activities in class working as an informant. Or they can discuss how to conduct the class out of the class with language teachers. for example, they can work together to analyze the objective of the teaching activity, design class activities, collect and sort out teaching materials, organize seminars and etc.

As to how to make the above mentioned joint-teaching successful, the author reckons that it lies in whether it can be a process of mutual improvement. On one hand, language teacher can help subject specialists deliver class content to students in English; on the other hand, subject specialists help language teachers in widening the horizon of knowledge and developing career. In order to achieve this purpose, both language teachers and subject specialist are supposed to have common interests in the subject they taught (Basturkmen, 2005). They need to have positive attitude. And also they need to be open-minded to accept this form of cooperation. The last but not least, there needs to be clear line between the responsibility of subject specialists' and that of language teachers'

\section{CONCLUSION}

The author in this article briefly introduces the background and development of ESP teaching and its practice in Changchun University of Science and Technology. Based on the results of the survey, students in CUST think both good mastery of English and necessary subject knowledge are the most important two qualifications for ESP teachers. To make the situation better, subject specialists can go abroad for further study to improve their capabilities in ESP teaching in the long run. In the short run, joint teaching between language teachers and subject specialist could be a shortcut to improve the situation. But cooperative teaching is a very complex process which involves many factors. Therefore, further study on joint teaching should be conducted as soon as possible.

\section{REFERENCES}

[1] Basturkmen, H. (2005). Ideas and Options in English for Specific Purposes (ESL \& Applied Linguistics Professional). London: Rutledge Press.

[2] Belcher D. D., A. M. Johns \&B. R. Paltridge. (2011). New Directions in English for Specific Purposes Research. Michigan: The University of Michigan Press.

[3] Cai Jigang \& Liao Leichao. (2010). Academic English or Subject English—Reorientation for College ESP Teaching. Beijing: Foreign Languages Teaching.

[4] Candlin, C. \& C, Edelhoff. (1982). Challenges: Teacher's Guide. London: Longman.

[5] Cunningsworth, A. (1984). Selecting \& Evaluating EFL Teaching Materials. London: Heinemann.

[6] Dudley-Evans, T. \& St. John. (1998). Development in English for Specific Purposes. Cambridge: Cambridge University Press.

[7] Grant, N. (1987). Making the Most of Your Textbooks. New York: Longman Group UK Limited.

[8] Harmer, J. (1983). The Practice of English Language Teaching. Longman: Hymes. D.

[9] Hedge, T. (2002). Teaching and Learning in the Language Classroom. Oxford: Oxford University Press.

[10] Hutchinson, T. \& A. Waters. (1987). English for Specific Purposes. Cambridge: Cambridge University Press.

[11] Robinson, P. C. (1980). English for Specific Purposes. Oxford: Pergamum Press.

Jifeng Cao was born in Panjin, Liaoning Province, China on September 5th, 1978, who has got a degree of Master of Arts in foreign linguistics and applied linguistics from Changchun University of Science and Technology, Changchun, Jilin Province, China in 2009.

As a Lecturer, he teaches English for science and technology for the English major at School of Foreign Languages, Changchun University of Science and Technology. Two published articles are as follows: [1] Should the Basic verbs "get" and "put" be Learned First for College Students in Their Spoken English Class? (Global Academic Research Association Limited, Journal of Culture \& International Languages 2013); [2] Will Interaction between Teacher and Students Affect Students' Attitudes toward EST Learning? (Global Academic Research Association Limited, Journal of EFL Learning and Teaching 2013). Previous research interests are Linguistics. At present he focuses on ESP teaching. 